\title{
Accumulation of debris on the deep sea floor off the French Mediterranean coast
}

\author{
F. Galgani ${ }^{1, *}$, A. Souplet ${ }^{3}$, Y. Cadiou ${ }^{2}$ \\ ${ }^{1}$ IFREMER, Ecotoxicology Laboratory, and ${ }^{2}$ Sismer, rue de l'Ile d'Yeu, F-44311 Nantes Cedex 03, France \\ ${ }^{3}$ Fisheries Research Laboratory, rue J. Vilar, F-34200 Sete, France
}

\begin{abstract}
The distribution and abundance of large marine debris were investigated on the continental slope and bathyal plain of the northwestern Mediterranean Sea during 3 oceanographic cruises undertaken in June 1994, July 1995 and April 1996. Different types of debris were enumerated, particularly pieces of plastic, plastic and glass bottles, metallic objects, glass and diverse materials including fishing gear. The results showed considerable geographical variation, with concentrations ranging from 0 to 78 pieces of debris ha ${ }^{-1}$ In most stations sampled, plastic bags accounted for a very high percentage (more than $70 \%$ ) of total debris. In the Gulf of Lions, only small amounts of debris were collected on the continental shelf. Most of the debris was found in canyons descending from the continental slope and in the bathyal plain, with high amounts occurring to a depth of more than $500 \mathrm{~m}$. An additional cruise was undertaken using the manned submersible Cyana (provided by IFREMER). Sixteen dives ( $46.07 \mathrm{~km}$ distance on the floor) conducted in canyons off Marseilles and Nice (France) ranging from 40 to $1448 \mathrm{~m}$ in depth, enabled us to locate accumulation areas. All these results are interpreted in terms of hydrological conditions.
\end{abstract}

KEY WORDS: Marine debris · Plastics - Continental slope Mediterranean Sea France Pollution

\section{INTRODUCTION}

Since the 1970s, various studies have dealt with the problem of debris in the marine environment, mainly in terms of quantitative analysis (Pruter 1987, Gilligan et al. 1992) and the effects on marine fauna (Laist 1987). Most of the data concern floating debris (Day \& Shaw 1987, Lecke-Mitchell \& Mullin 1992) or litter along the coast, particularly on beaches where it is abundant (Pruter 1987). Although the debris is quite variable in type, plastics account for the major part because of their poor degradability. Glass or metal objects as well as fishing nets are also found in appreciable quantity. The consequences of this pollution are considerable. The entanglement of marine species, particularly turtles (Carr 1987), but also mammals and birds (Coe 1990), has been frequently described. Moreover, the thousands of tons of plastics in the sea constitute a considerable source of pollutants, notably

•E-mail: fgalgani@ifremer.fr polyethylene and polypropylene (Palmisano \& Petigrew 1992), which affect organisms (Burgess-Cassler et al. 1991). The esthetic impact of larger debris is yet another objectionable result. Finally, the repercussions on coastal economic activity, particularly fishing, have been demonstrated (Takehama 1990, Nash 1992).

The distribution of the debris is another important factor. High concentrations are found near shipping lanes (Gottfried et al. 1987), around fishing areas (Pruter 1987) and in oceanic current convergence zones (Pruter 1987). Conditions on the French coast have been surveyed in a complete study of coastal beaches (Loubersac \& Bodennec 1982), showing the influence of currents on the distribution of debris. Little information is currently available concerning larger debris on the coastal continental shelf since considerable means are required for an undertaking of such magnitude. Recently, the presence of large amounts of debris on the continental shelf of the Bay of Biscay and around northwestern Mediterranean towns has been demonstrated (Galgani et al. 1995a, b). The presence of debris has also been recorded on the deep sea floor in the eastern 
Mediterranean (Galil et al. 1995). The present study is a first attempt to evaluate the presence of different types of debris found on the continental slope and the bathyal plain of the northwestern Mediterranean Sea where the economic impact of tourism, fishing and coastal urban populations is important. Results give scientific and technical bases for extrapolation to larger areas.

\section{METHODS}

Two cruises were undertaken in June 1994 and July 1995 aboard the RV 'L'Europe'. These cruises provided sampling respectively of 69 and 72 stations along the entire continental shelf and adjacent canyons of the Gulf of Lions. The data were recorded in conjunction with a project to study fish stocks. For the cruises in the Gulf of Lions, specimens were obtained using a Goc73 bottom trawl net (Bertrand 1994) with $16 \mathrm{~m}$ and $10 \mathrm{~mm}$ for mouth and mesh widths respectively. The tows were conducted over a period of 30 to 60 min, and 7 types of debris were counted: plastic bags, plastic bottles, glass, metallic objects, cloth or leather objects, parts of fishing gear and diverse objects. Results are given as the number of objects gathered per category and station for a trawling period of $30 \mathrm{~min}\left(0.0444 \mathrm{~km}^{2}\right)$. To map curves with the same concentrations of debris, data were computed using Surfer software, version IV (Surfer Inc., Golden, CO, USA), in conjunction with cartography software (Karto, Y. Cadiou, IFREMER). A third cruise was undertaken in April 1996 providing samples at 15 stations between 500 and $1600 \mathrm{~m}$ depth in the southern part of the Gulf of Lions, including canyons and bathyal plain. The tows were conducted over a period of 20 to 60 min using a honfleur type (with a pole) bottom trawl (Gage \& Tyler 1991) with $62 \mathrm{~m}$ and $10 \mathrm{~mm}$ for mouth and mesh widths respectively. Debris was counted as in previous cruises for a trawling period of $60 \mathrm{~min}\left(0.0172 \mathrm{~km}^{2}\right)$

An additional cruise (December 1995) involving 16 dives was conducted to locate accumulation areas around Marseilles and Nice. Dives were conducted using the submersible Cyana (IFREMER) at the locations indicated in Fig. 1, using bathymetric charts from the EMM 1000 sea beam (Atalante, IFREMER). The positions and routes of the submersible were obtained using an acoustic positioning system, except for Dives 12 and 14 (depth $<100 \mathrm{~m}$ ) when a floating buoy was used. A summary of the dives is given in Table 1

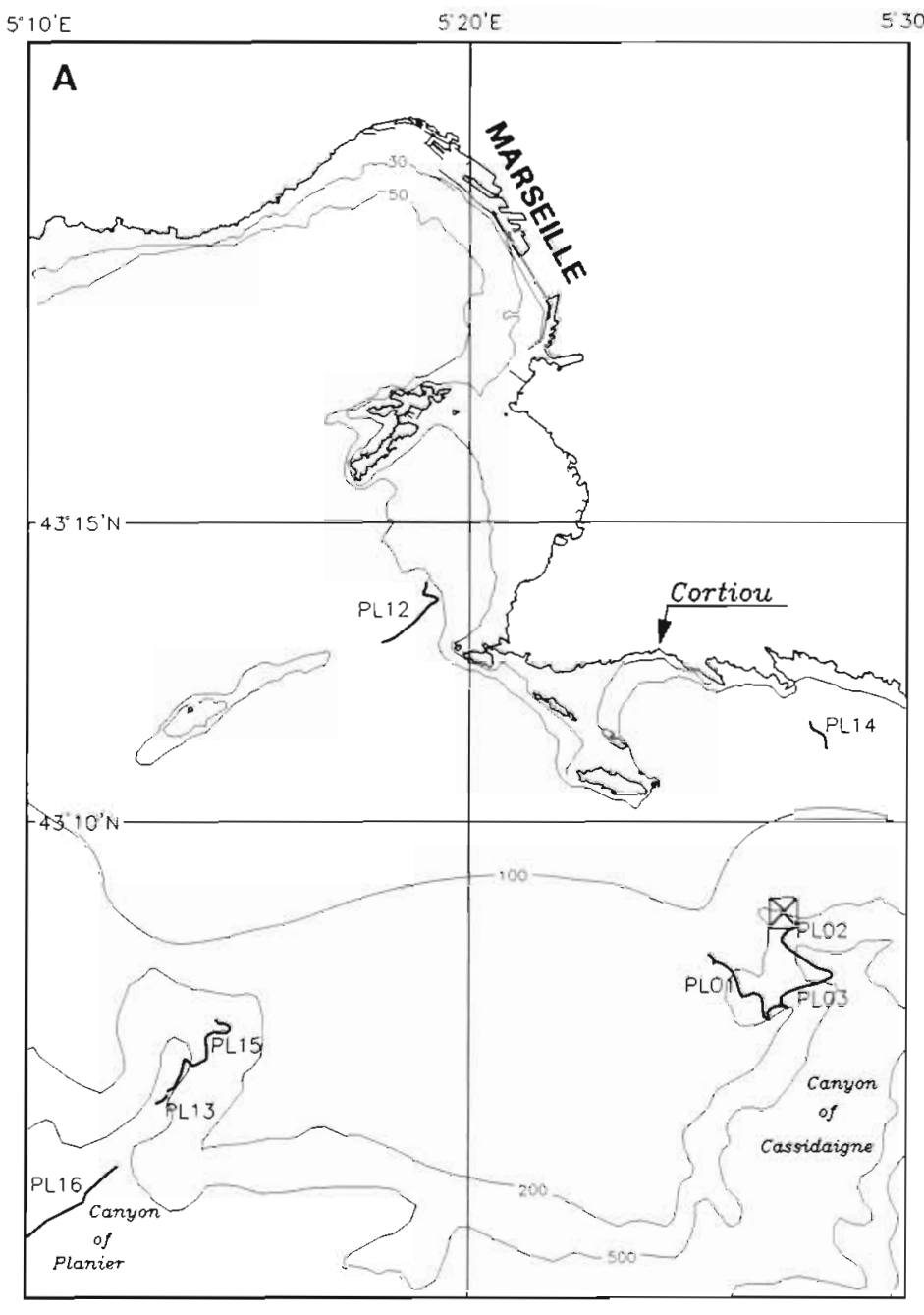

Fig. 1 (above and facing page). Locations of dives with the Cyana submersible. $(\nabla)$ Location of red mud effluent

\section{RESULTS}

The amounts of larger debris collected during trawling operations in 1994 in the Gulf of Lions differed by category of object (Fig. 2), ranging from 1 to 44 pieces of debris per station. Plastics were most frequent, with a mean percentage for all stations of $70.6 \%$. The largest abundance of debris was found around Marseilles. Results for the 1995 cruise confirmed the presence of debris in adjacent canyons of the continental shelf, with up to 65 pieces of larger debris at depths of 500 to $750 \mathrm{~m}$. In all cases, plastic bags composed a large part of total debris. All plastic objects combined (bags, bottles, diverse objects) sometimes accounted for $90 \%$ or more of the total debris.

The amounts of debris on the continental shelf were found to be lower, with a maximum of 10 pieces $(6$ plastics) found in 1994 at $42^{\circ} 53.19^{\prime} \mathrm{N}, 03^{\circ} 38.62^{\prime} \mathrm{E}$. The 


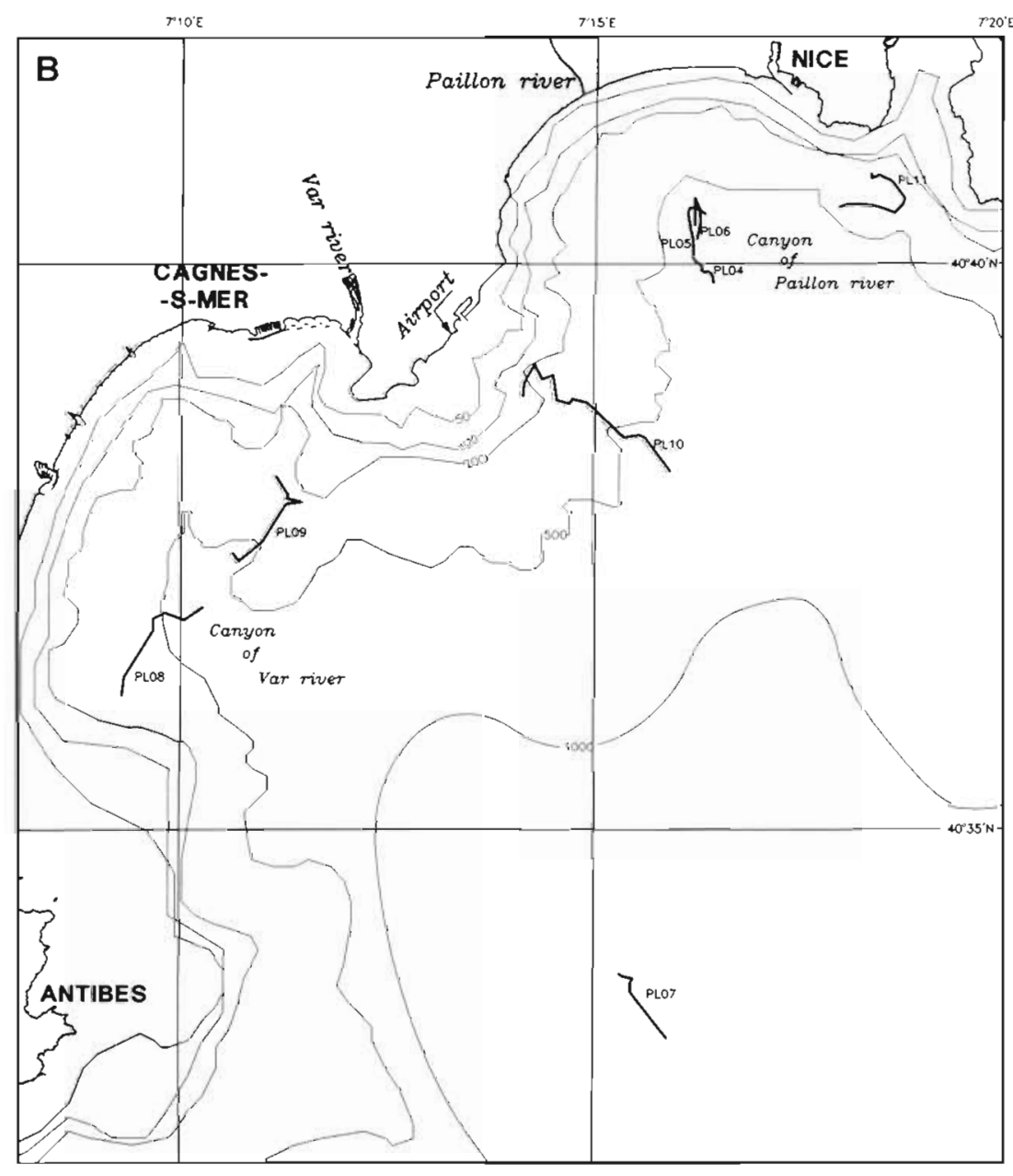

2.39 pieces of debris per $100 \mathrm{~m}$, including $71.8 \%$ plastics. Depending on the site, quantities ranged from 0.30 (Dive 10 , Nice airport) to 11.23 (Dive 12, Marseilles). However, the amounts were very similar from one dive to another in the same area, with mean quantities of $0.75,9.40$, 1.67 and 3.34 pieces of debris per $100 \mathrm{~m}$ in distance (with no piles) for the Cassidaigne, Paillon, Var and Planier canyons respectively.

A total of 38 piles was recorded, which were located mainly in canyons such as Paillon, Var and Planier. Debris was systematically counted in Planier canyon, giving a total number of 190 pieces for 6 piles. In this case, debris in piles accounted for $50.5 \%$ of the total number of pieces. Pile structures differed according to site. In Var canyon, only a few pieces of debris were recorded on the bottom, whereas most of the debris was accumulated in a side channel of the canyon (Fig. 5A). Debris retention was also observed at the end of Dive 8 owing to the presence on the sea floor of large objects of natural origin (trees) as well as anthropogenic inputs such as wrecks (Fig. 5B). A third type of pile was observed in Planier

mean weight of plastics for 107 objects collected during 12 trawling experiments was $22.26 \pm 9.27 \mathrm{~g}(\mathrm{p}=0.05)$. Mapping isoabundance curves (Fig. 3) enabled us to locate accumulation sites more precisely. Two different areas with high rates of deposition were found, the first around Marseilles and the other in adjacent canyons of the western part of the shelf. Although these sites accumulated most of the debris, sinking materials such as bottles were located on the continental shelf, mainly in the eastern part of the Gulf of Lions $\left(43^{\circ} 15^{\prime} \mathrm{N}, 4^{\circ} 45^{\prime} \mathrm{E}\right)$.

This was confirmed by counting the debris during the third cruise providing samples in the bathyal plain where debris was shown to accumulate (Fig. 4, Table 3). Concentration varied from 24 to 132 items tow ${ }^{-1}$ including $85 \%$ plastics. Table 2 summarizes concentrations according to depth. The results clearly demonstrate the localization of debris in deeper areas.

Sixteen dives enabled us to quantify the debris along a distance of $46.07 \mathrm{~km}$ between $1448 \mathrm{~m}$ (Dive 12) and $40 \mathrm{~m}$ depth (Dive 14). Table 1 summarizes all observations concerning debris. For all dives, 1103 pieces of debris (with no piles) were recorded, giving a mean value of canyon where debris (mainly bottles) had accumulated around large rocks buried in the sea floor (Fig. 5C).

\section{DISCUSSION}

Various methods are available for evaluating the abundance of debris on the sea floor including photography, diving, submersibles and trawling. From these methods, trawling surveys appear to provide the most statistically satisfying results for evaluating debris (Goldberg 1994). They have been widely used for fish stocks assessment and for benthic biomass evaluation. Despite recent development of sophisticated photography for biomass evaluation of deep sea organisms (Chevaldonné \& Jollivet 1993), they appear to give reliable results in terms of quantitative evaluation. However, it is difficult to determine the exact amounts of larger debris on the continental shelf since considerable means are required to cover the area thoroughly. Estimation of total debris based on the total mean calculated for the first cruise (1994) 
Table 1. Description of dives and data on debris collected during the fourth cruise

\begin{tabular}{|c|c|c|c|c|c|c|c|c|c|}
\hline Dive & Location & $\begin{array}{l}\text { Depth } \\
(m)\end{array}$ & Positions & Duration & $\begin{array}{l}\text { Distance } \\
\qquad(\mathrm{m})\end{array}$ & Debris & $\begin{array}{l}\text { Debris } \\
\text { per } 100 \mathrm{~m}\end{array}$ & $\begin{array}{c}\text { Plastics } \\
(\%)\end{array}$ & Piles \\
\hline 1 & Cassidaigne & $445-144$ & $\begin{array}{l}43^{\circ} 06.52^{\prime} \mathrm{N}, 05^{\circ} 26.26^{\prime} \mathrm{E} \\
43^{\circ} 07.36^{\prime} \mathrm{N}, 05^{\circ} 25.40^{\prime} \mathrm{E}\end{array}$ & $3 \mathrm{~h}, 41 \mathrm{~min}$ & 5190 & 63 & 1.20 & $27(42)$ & 0 \\
\hline 2 & Cassidaigne & $645-550$ & $\begin{array}{l}43^{\circ} 07.14^{\prime} \mathrm{N}, 05^{\circ} 28.21^{\prime} \mathrm{E} \\
43^{\circ} 06.54^{\prime} \mathrm{N}, 05^{\circ} 27.40^{\circ} \mathrm{E}\end{array}$ & $3 \mathrm{~h}, 21 \mathrm{~min}$ & 4528 & 17 & 0.35 & $10(58)$ & 0 \\
\hline 3 & Cassidaigne & $655-274$ & $\begin{array}{l}43^{\circ} 07.28^{\prime} \mathrm{N}, 05^{\circ} 28.07^{\prime} \mathrm{E} \\
43^{\circ} 06.32^{\prime} \mathrm{N}, 05^{\circ} 26.47^{\prime} \mathrm{E}\end{array}$ & $4 \mathrm{~h}, 20 \mathrm{~min}$ & 6148 & 39 & 0.63 & $25(64)$ & 0 \\
\hline 4 & Paillon & $820-640$ & $\begin{array}{l}43^{\circ} 40.50^{\prime} \mathrm{N}, 07^{\circ} 16.45^{\prime} \mathrm{E} \\
43^{\circ} 40.16^{\prime} \mathrm{N}, 07^{\circ} 16.16^{\prime} \mathrm{E}\end{array}$ & $1 \mathrm{~h}, 57 \mathrm{~min}$ & 2181 & 227 & 10.40 & $178(78.4)$ & 1 \\
\hline 5 & Paillon & $637-600$ & $\begin{array}{l}43^{\circ} 40.16^{\prime} \mathrm{N}, 07^{\circ} 16.16^{\prime} \mathrm{E} \\
43^{\circ} 40.32^{\prime} \mathrm{N}, 07^{\circ} 16.19^{\prime} \mathrm{E}\end{array}$ & $1 \mathrm{~h}, 31 \mathrm{~min}$ & 920 & 71 & 7.17 & $48(67.6)$ & $7(30)^{d}$ \\
\hline 6 & Paillon & $646-575$ & $\begin{array}{l}43^{\circ} 40.32^{\prime} \mathrm{N}, 07^{\circ} 16.19^{\prime} \mathrm{E} \\
43^{\circ} 43.27^{\prime} \mathrm{N}, 07^{\circ} 16.18^{\prime} \mathrm{E}\end{array}$ & $1 \mathrm{~h}, 17 \mathrm{~min}$ & 694 & 59 & 8.5 & $31(52.5)$ & 10 \\
\hline 7 & Var & $1442-1408$ & $\begin{array}{l}43^{\circ} 33.49^{\prime} \mathrm{N}, 07^{\circ} 15.50^{\prime} \mathrm{E} \\
43^{\circ} 33.36^{\prime} \mathrm{N}, 07^{\circ} 15.12^{\prime} \mathrm{E}\end{array}$ & $1 \mathrm{~h}, 05 \mathrm{~min}$ & 1590 & 21 & 1.32 & $15(71)$ & 0 \\
\hline 8 & Var & $684-370$ & $\begin{array}{l}43^{\circ} 37.00^{\prime} \mathrm{N}, 07^{\circ} 1012^{\prime} \mathrm{E} \\
43^{\circ} 36.15^{\prime} \mathrm{N}, 07^{\circ} 09.13^{\prime} \mathrm{E}\end{array}$ & $2 \mathrm{~h}, 00 \mathrm{~min}$ & 2916 & 80 & 2.74 & $58(72.5)$ & 4 \\
\hline 9 & Var & $550-440$ & $\begin{array}{l}43^{\circ} 37.27^{\prime} \mathrm{N}, 07^{\circ} 10.49^{\prime} \mathrm{E} \\
43^{\circ} 38.06^{\prime} \mathrm{N}, 07^{\circ} 11.14^{\prime} \mathrm{E}\end{array}$ & $2 \mathrm{~h}, 26 \mathrm{~min}$ & 3213 & 28 & 0.87 & $20(71.4)$ & 1 \\
\hline 10 & Nice & $704-99$ & $\begin{array}{l}43^{\circ} 38.09^{\prime} \mathrm{N}, 07^{\circ} 15.57^{\prime} \mathrm{E} \\
43^{\circ} 38.50^{\prime} \mathrm{N}, 07^{\circ} 15.56^{\prime} \mathrm{E}\end{array}$ & $2 \mathrm{~h}, 52 \mathrm{~min}$ & 5164 & 16 & 0.30 & $13(81)$ & 0 \\
\hline 11 & Villefranche & $467-330$ & $\begin{array}{l}43^{\circ} 40.39^{\prime} \mathrm{N}, 07^{\circ} 18.59^{\prime} \mathrm{E} \\
43^{\circ} 40.38^{\prime} \mathrm{N}, 07^{\circ} 18.16^{\prime} \mathrm{E}\end{array}$ & $1 \mathrm{~h}, 12 \mathrm{~min}$ & 1390 & 14 & 1.07 & $5(35.7)$ & 0 \\
\hline 12 & Marseilles & $58-40$ & $\begin{array}{l}43^{\circ} 13.00^{\prime} \mathrm{N}, 05^{\circ} 18.00^{\prime} \mathrm{E} \\
43^{\circ} 14.00^{\prime} \mathrm{N}, 05^{\circ} 19.00^{\prime} \mathrm{E}\end{array}$ & $2 \mathrm{~h}, 45 \mathrm{~min}$ & 1388 & 156 & 11.23 & $109(69.8)$ & 2 \\
\hline 13 & Planier & $669-565$ & $\begin{array}{l}43^{\circ} 05.20^{\prime} \mathrm{N}, 43^{\circ} 05.27^{\prime} \mathrm{N} \\
05^{\circ} 12.57^{\prime} \mathrm{E}, 05^{\circ} 13.06^{\prime} \mathrm{E}\end{array}$ & o h, $39 \mathrm{~min}$ & 299 & 6 & 2.21 & $5(83.3)$ & 0 \\
\hline 1.4 & Cortiou & $93-85$ & $\begin{array}{l}43^{\circ} 11.08^{\prime} \mathrm{N}, 05^{\circ} 28.09^{\prime} \mathrm{E} \\
43^{\circ} 11.41^{\prime} \mathrm{N}, 05^{\circ} 27.43^{\prime} \mathrm{E}\end{array}$ & $1 \mathrm{~h}, 24 \mathrm{~min}$ & 1248 & 44 & 3.52 & $21(47.7)$ & 1 \\
\hline 15 & Planier & $555-340$ & $\begin{array}{l}43^{\circ} 05.16^{\prime} \mathrm{N}, 43^{\circ} 06.51^{\prime} \mathrm{N} \\
05^{\circ} 13.08^{\prime} \mathrm{E}, 05^{\circ} 14.18^{\prime} \mathrm{E}\end{array}$ & $3 \mathrm{~h}, 11 \mathrm{~min}$ & 6018 & 126 & 2.09 & $76(60.3)$ & 6 \\
\hline 16 & Planier & $993-795$ & $\begin{array}{l}43^{\circ} 03.00^{\prime} \mathrm{N}, 05^{\circ} 10.00^{\prime} \mathrm{E} \\
43^{\circ} 05.11^{\prime} \mathrm{N}, 05^{\circ} 12.03^{\prime} \mathrm{E}\end{array}$ & $2 \mathrm{~h}, 29 \mathrm{~min}$ & 3185 & 186 & 5.83 & $151(81.1)$ & $(190)^{b}$ \\
\hline Total & & & & & 46072 & 1103 & 2.39 & $792(71.8)$ & \\
\hline
\end{tabular}

Table 2. Description of sampling in the southern Gulf of Lions (Cruise 3)

\begin{tabular}{|c|c|c|c|c|c|}
\hline Position & Depth $(\mathrm{m})$ & Trawling time (min) & Speed (knots) & Debris per $10000 \mathrm{~m}^{2}$ & $\%$ plastics \\
\hline $42^{\circ} 42.5^{\prime} \mathrm{N}, \quad 44^{\circ} 6.6^{\prime} \mathrm{E}$ & $986-1030$ & 30 & 1.5 & 14 & 91 \\
\hline $42^{\circ} 43.9^{\prime} \mathrm{N}, \quad 42^{\circ} 9.5^{\prime} \mathrm{E}$ & $1129-1193$ & 40 & 1.5 & 77 & 82 \\
\hline $42^{\circ} 33.4^{\prime} \mathrm{N}, \quad 40^{\circ} 8.2^{\prime} \mathrm{E}$ & $1096-1179$ & 60 & 1.5 & 67 & 86 \\
\hline $42^{\circ} 27.7^{\prime} \mathrm{N}, 40^{\circ} 7^{\prime} \mathrm{E}$ & $1136-1157$ & 60 & 15 & 26 & 78 \\
\hline $42^{\circ} 19.92^{\prime} \mathrm{N}, 40^{\circ} 0.4^{\prime} \mathrm{E}$ & $1600-1630$ & 60 & 1.3 & 49 & 87 \\
\hline $42^{\circ} 32.67^{\prime} \mathrm{N}, 35^{\circ} 0.9^{\prime} \mathrm{E}$ & $1086-1086$ & 23 & 1.1 & 37 & 74 \\
\hline $42^{\circ} 22.8^{\prime} \mathrm{N}, 34^{\circ} 4.5^{\prime} \mathrm{E}$ & $1314-1321$ & 41 & 1.3 & 24 & 84 \\
\hline $42^{\circ} 20.14^{\prime} \mathrm{N}, 32^{\circ} 8.2^{\prime} \mathrm{E}$ & $650-725$ & 30 & 1.3 & 5.5 & 9.3 \\
\hline $42^{\circ} 25.25^{\prime} \mathrm{N}, 31^{\circ} 4^{\prime} \mathrm{E}$ & $100-101$ & 30 & 1.5 & 13 & 89 \\
\hline $41^{\circ} 40.62^{\prime} \mathrm{N}, 33^{\circ} 2.2^{\prime} \mathrm{E}$ & $500-550$ & 30 & 1.5 & 28 & 78 \\
\hline $41^{\circ} 34.08^{\circ} \mathrm{N}, 33^{\circ} 0.8^{\prime} \mathrm{E}$ & $1160-1160$ & 30 & 1.5 & 1.3 & 89 \\
\hline $42^{\circ} 14.27^{\prime} \mathrm{N}, 34^{\circ} 4.2^{\prime} \mathrm{E}$ & $1153-1275$ & 45 & 1.5 & 47 & 78 \\
\hline $42^{\circ} 29.3^{\circ} \mathrm{N}, 34^{\circ} 0.8^{\prime} \mathrm{E}$ & $744-725$ & 26 & 1.5 & 56 & 90 \\
\hline $42^{\circ} 21.15^{\circ} \mathrm{N}, 32^{\circ} 3.6^{\prime} \mathrm{E}$ & $534-634$ & 24 & 1.5 & 40 & 98 \\
\hline
\end{tabular}



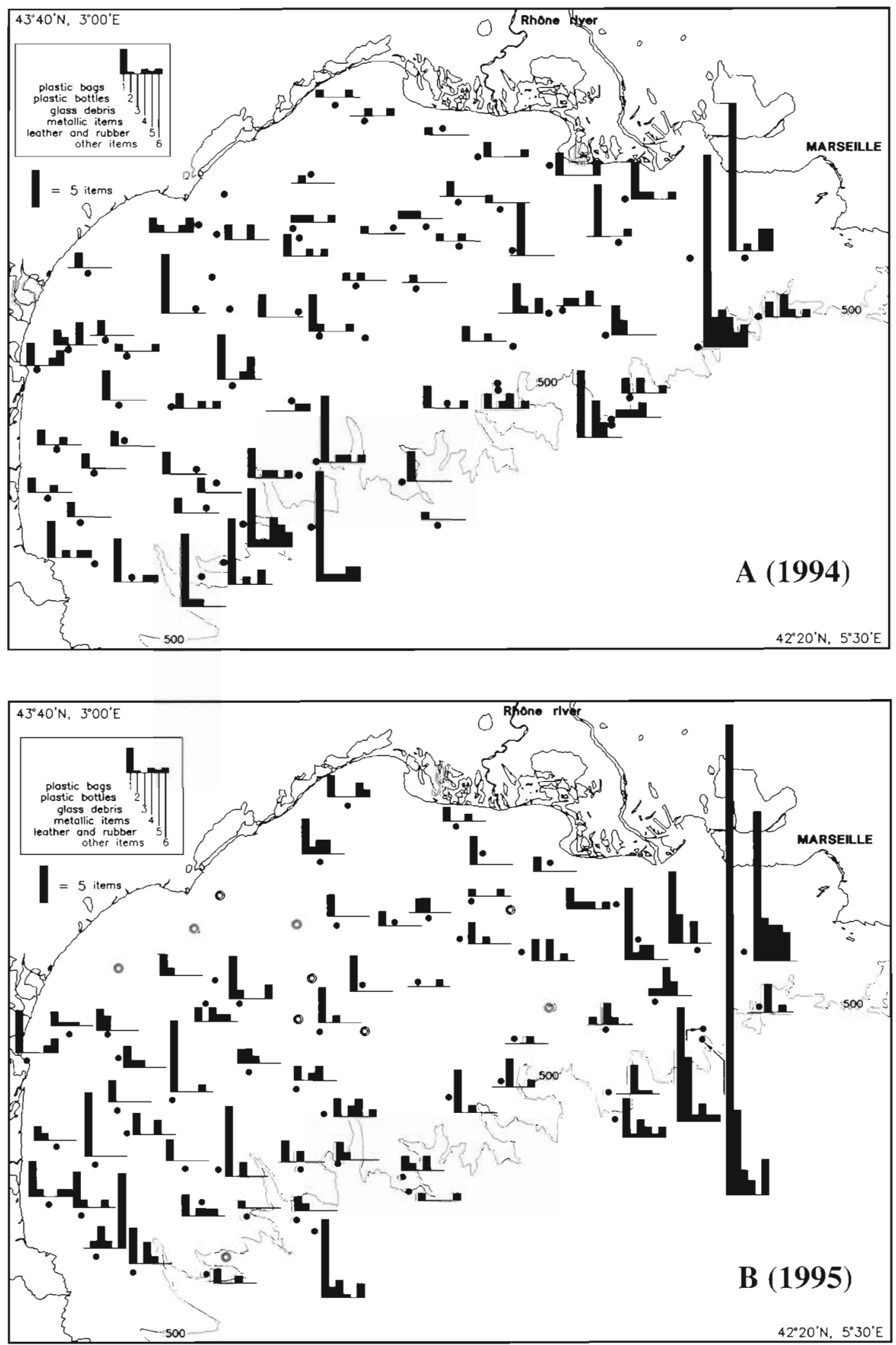

Fig. 2. Quantities of debris collected in April 1994 and June 1995 on the continental shelf and adjacent canyons of the Gulf of Lions ( 30 min trawling tows, $0.0444 \mathrm{~km}^{2}$ ). Sampling procedures are described in 'Methods' 

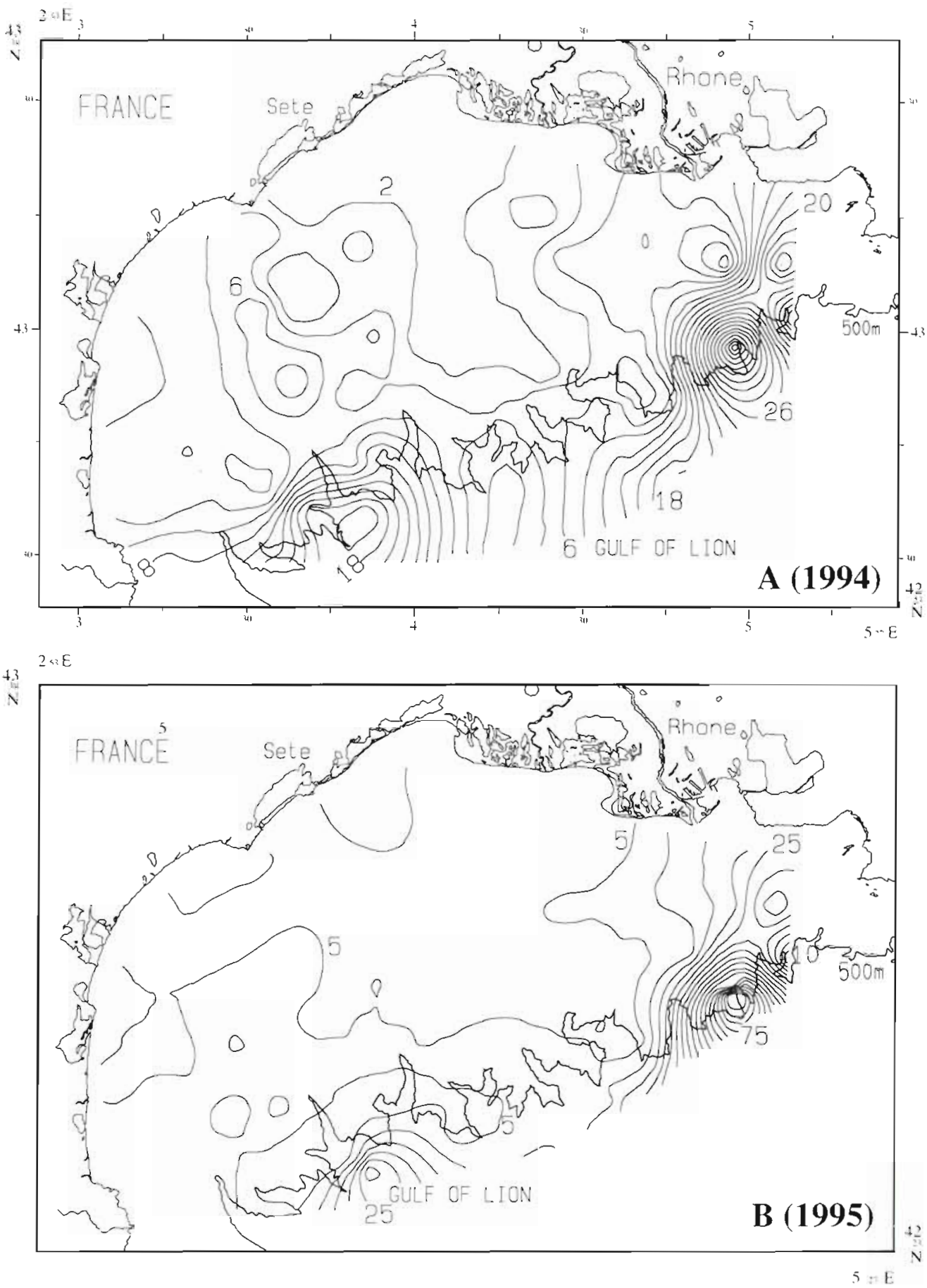

Fig. 3. Isoconcentration curves for tolal debris in the Gulf of Lions. Results were obtained using the kriging method and Surfer software (see 'Methods') with a $35 \times 35$ grid; data are from Fig. 2

Table 3. Densities of debris in the Gulf of Lions in relation to depth. Values were calculated from cruises ın 1995 and 1996

\begin{tabular}{|lccccc|}
\hline Depth $(\mathrm{m})$ & Tows & Total area $\left(\mathrm{km}^{2}\right)$ & Total debris & Plastics & Debris $\mathrm{km}^{2}$ \\
\hline$<200$ & 57 & 3.03 & 337 & $229(68 \%)$ & 11.2 \\
$200-1000$ & 21 & 0.816 & 568 & $483(85 \%)$ & 696 \\
$>1000$ & 10 & 0.17 & 631 & $537(85 \%)$ & 3712 \\
\hline
\end{tabular}




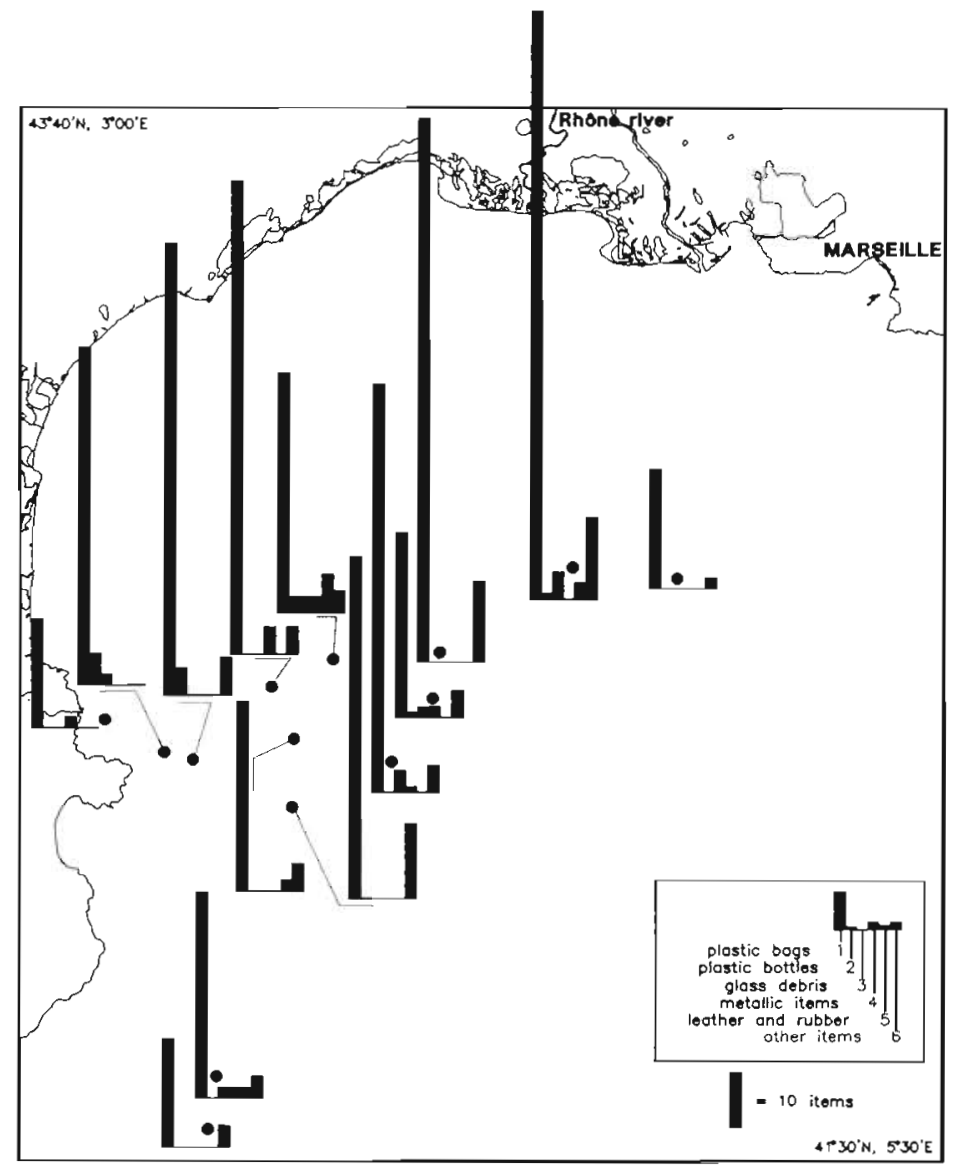

Fig. 4. Quantities of debris collected in April 1996 between 500 and 1636 $\mathrm{m}$ in the southern part of the Gulf of Lion $160 \mathrm{~min}$ trawling tows, 0.017 $\mathrm{km}^{2}$ ). Sampling procedure is described in 'Methods' Note the values are given for areas of $40 \%$ of those from cruises 1 and 2 (Fig. 1) ation of quantities simply by trawling could thus lead to significant underestimations.

Nonetheless, debris mapping provided valuable information on the factors influencing its distribution. The presence of large amounts of debris off Marseilles and to a lesser extent off other large cities such as Nice was related to the urban activity in those areas. Moreover, in the Gulf of Lions, debris may have been swept up along the coast because of general current conditions (Millot 1987, Brasseur 1991). Currents bring water masses up from the south along the Italian coast, down from the north along the Spanish coast and from east to west along the French coast.

The transportation of debris in relation to the local upwellings occurring along the coast of the Gulf must also be considered (Millot \& Wald 1980, Millot et al. 1994). Surprisingly, however, only low amounts of debris were found in sites around the mouth of the Rhone River. Yet this may have been due to the importance of the flow, which induces rapid dilution of the debris and transport to the south. This is well illustrated by isoconcentration maps which clearly show the disappearance of slow-sinking debris on the shelf adjacent to the delta. It is likely that debris is mixed with inputs carried by the current from the Marseilles area, thus accounting for the accumulation of solid particles in canyons off the Gulf of Lions (Beckers et al. 1991, Brasseur 1991). except in the central part of the Gulf where gave 0.99 pieces of debris ha-1. For a total continental shelf area of $12000 \mathrm{~km}^{2}$ (not exceeding $200 \mathrm{~m}$ in depth), this represents 1.188 million pieces of debris, $77 \%$ of which were plastics, including $92.8 \%$ bags. For 1995, the estimated amount of debris for the Gulf of Lions was $1.334 \times 10^{6}$ The mean weight (22.6 g) of plastic debris calculated from 12 tows performed during the 1994 cruise yielded estimated total amounts of $26.84 \mathrm{t}$ (1994) and $30.16 \mathrm{t}$ (1995) of plastics on the continental shelf of the entire gulf. In comparison with the total quantity collected in the entire continental shelf from the northwestern Mediterranean Sea (19.3 pieces of debris ha ${ }^{-1}, 3045$ t; Galgani et al. 1995b), amounts were very low. However, these results are partial since they concern only those areas in which trawling operations could be carried out. Movements of debris in these areas were subject to hydrodynamic conditions which created few obstacles for the retention and accumulation of objects. For Dive 16 , more than $50 \%$ of the debris was located in piles close to rocks and therefore untrawlable. Evaluresuspension occurs (Brun-Cottan \& Li 1991). Most of the debris found during our cruises was not buoyant material and probably sank in those areas. The accumulation of contaminants was also apparent in areas where the concentration of some anthropogenic chemicals was higher than on the continental shelf, especially in the western part of the Gulf of Lions (Nolting 1991).

One interesting finding was that debris distribution was stable in the Gulf of Lions between April 1994 and June 1995, whereas observations for the continental shelf of the Bay of Biscay (Galgani et al. 1995a) showed that the location of accumulation sites varied considerably. Local water movement was slow at deeper points, which was a major reason for the accumulation of larger quantities of debris in those areas. This is illustrated by the differences in abundance of debris recorded between Dive 10 in a bathyal plain area with a strong in situ current ( 0.30 pieces of debris per $100 \mathrm{~m}$ ) and those in the Planier (Dives 13, 15 and 16) and Paillon canyons (Dives 4 to 6 ) where the quantities were greater and water movements slower in the depths. 

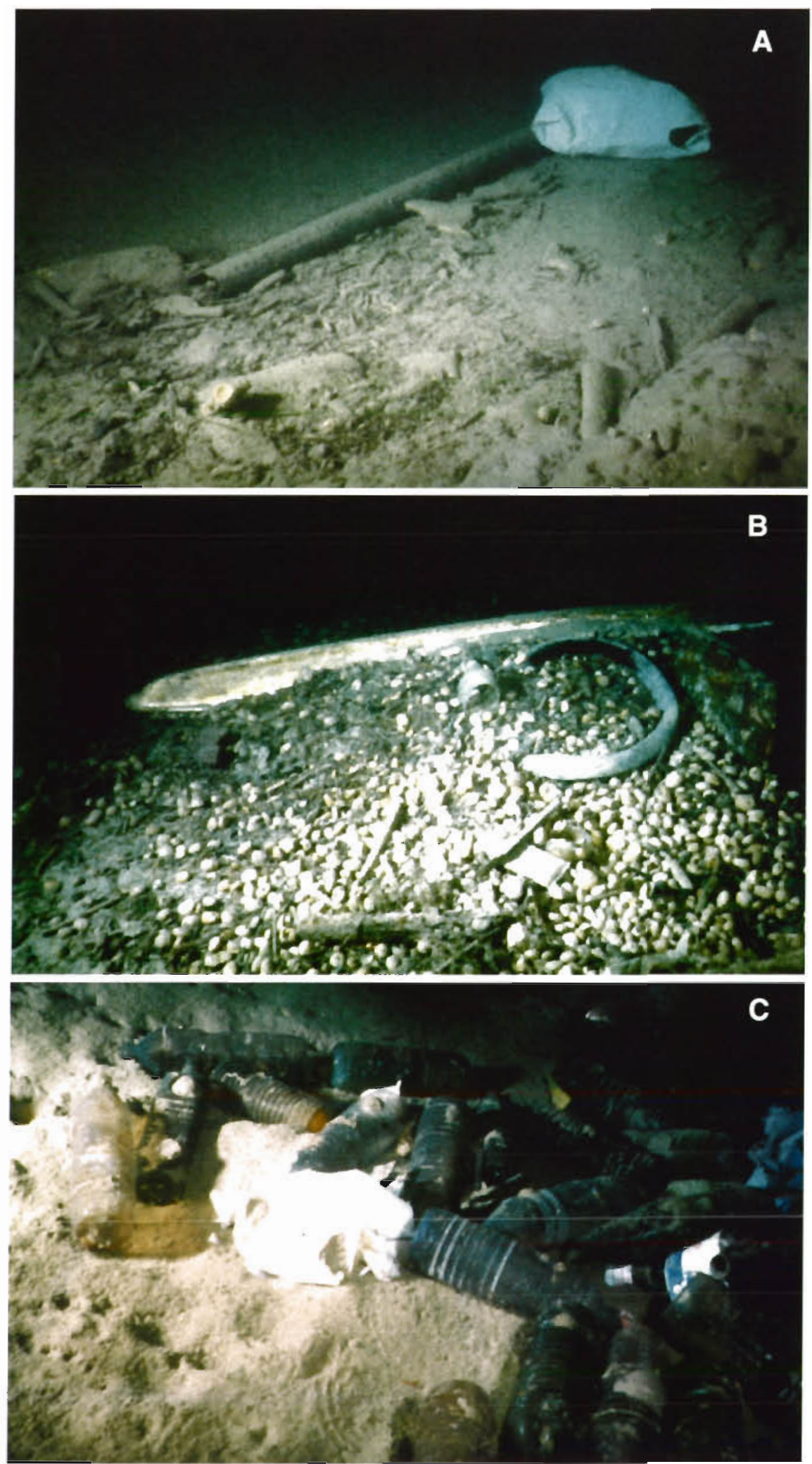

Fig. 5. Types of accumulation areas for debris observed durng diving experiments. (A) Accumulation of debris along a channel (Dive 8, depth $687 \mathrm{~m}$, position $43^{\circ} 37.00^{\prime} \mathrm{N}, 07^{\circ} 10.2^{\prime} \mathrm{E}$ ). (B) Accumulation of debris around a wreck (Dive 8, depth $438 \mathrm{~m}$, position $43^{\circ} 36.17^{\prime} \mathrm{N}, 07^{\circ} 09.12^{\prime} \mathrm{E}$ ). (C) Accumulation of debris around rocks (Dive 16, depth $992 \mathrm{~m}$, position $43^{\circ} 03.00^{\prime} \mathrm{N}, 05^{\circ} 10.00^{\prime} \mathrm{E}$ ) 
The Cassidaigne canyon is a special case. Debris densities were low and piles were inexistent despite the proximity of Marseilles and the abundance of debris in an urban area (Galgani et al. 1995b). Inputs of fine sediments related to the presence of submerged deposits of red mud at a depth of $350 \mathrm{~m}$ in the canyon cause very high sedimentation, resulting in an alteration of benthic populations. These large deposits of around $300 \mathrm{t} \mathrm{d}^{-1}$ have created a plume of 20 to $30 \mathrm{~km}^{2}$. with the main flow passing through the canyon. In addition to the effects on the fauna, the debris itself is covered over and buried in a thick layer of pulverulent sediments originating from these deposits. For Var canyon, densities are lower because of the strong current induced by the Var River, as confirmed by localization of debris in channels adjacent to the canyon bed where the current is slow and by the presence of vegetable debris (tree trunks, leaves) related to a strong current in the depths coming from the estuary and localized mainly in the center of the canyon.

The accumulation of piles of debris is also related to geomorphological factors such as the conformation of the sea floor, particularly the existence of rocks, crevasses and other features favorable to accumulation. Likewise, anthropogenic factors need to be considered. In fact, the accumulation of debris in Paillon canyon or Marseilles harbor is related to the respective inputs of the cities of Nice and Marseille. For Nice, objects relative to tourism, such as the wreckage of small boats, were observed in addition to the classic debris.

In oceanographic terms, the data obtained provide information on current patterns in the areas studied and on the stability of situations in the Gulf of Lions.

It may be concluded that different known sources of debris (Gottfried et al. 1987, Pruter 1987) exist in the northwestern Mediterranean Sea, which are responsible for accumulations in canyons descending from the continental slope alone with the bathyal plain and are affected by local hydrodynamics. Studies are now in progress to investigate conditions on the deep sea floor.

Acknowledgements. We thank all the participants in the cruises for their assistance in counting the debris and for some observations. We are grateful to L. Giboire for constructing the figures, M. J. Thébaud for secretarial assistance, Y Cadiou for helpful advice in computing the data and J. Gray for reviewing the English translation

\section{LITERATURE CITED}

Beckers JM, Djenidi S, Nihoul CJ (1991) Modellıng the western Mediterranean: from hydrology to hydrodynamics Thurd workshop on the north-west Mediterranean Sea,
Texel, October 1991 Water Pollut Res 28:19-37

Bertrand J (1994) Campagne internationale de chalutage démersal en Méditerranée (MEDITS) - manuel des protocoles. Etude 94/047 IFREMER/CE XII Annexes

Brasseur P (1991) Initialization of 3D models of the western Mediterranean and the Gulf of Lion: application of a variational method to the reconstruction of data fields. Third workshop on the north-west Mediterranean Sea, Texel, October 1991. Water Pollut Res 28:39-50

Brun-Cottan JC, Lı ZH (1.991) Sediment resuspension in the Gulf of Lion. Third workshop on the north-west Mediterranean Sea, Texel, October 1991 Water Pollut Res 28 $51-62$

Burgess-Cassler A, Imam SH, Gould JM (1991) High molecular weight amylase activities from bacteria degrading starch plastic film. Appl Environ Microbiol 57:612-614

Carr A (1987) Impact of non degradable marine debris on the ecology and survival outlook of sea turtles. Mar Pollut Bull $18,6(\mathrm{~B}): 352-357$

Chevaldonne P, Jollivet D (1993) Videoscopic study of deepsea hydrothermal vent alvinellid polychaete populations: biomass estimation and behaviours. Mar Ecol Prog Ser 95: $251-262$

Coe JM (1990) A review of marine debris research, education, and mitigation in the North Pacific. In: Shomura RS, Godfrey ML (eds) Proceedings of the Second International Conference on Marine Debris. Honolulu, Hawaii, April 2-7, 1989. US Dept of Commerce, NOAA-TM-NMFSSWFSC-154, Washington, DC, p 19-49

Day RH. Shaw DG (1987) Patterns in the abundance of pelagic plastic and tar in the North Pacific ocean, 19761985. Mar Pollut Bull 18,6(B):311-316

Gage JD. Tyler TA (1991) Methods of study of organisms on the deep sea floor In: Deep sea biology: a natural history of organisms at the deep sea floor. Cambridge University Press, Cambridge, p 31-59

Galgani F, Burgeot $T$, Bocquene $G$, Vincent $F$, Leaute JP, Labastie J, Forest A, Guichet R (1995a) Distribution and abundance of debris on the continental shelf of the Bay of Biscay and in the Seine bay. Mar Pollut Bull 30,1:58-62

Galgani F, Jaunet S, Campillo A, Guenegan X, His E (1995b) Distribution and abundance of debris on the continental shelf of the north-western Mediterranean Sea. Mar Pollut Bull 30, 11:713-717

Galil BS, Golik A. Tuerkay M (1995) Litters at the bottom of the sea. A sea bed survey in the eastern Mediterranean Sea. Mar Pollut Bull 30,1:22-24

Gllligan MR, Pitts S, Richardson PJ, Kozel TR (1992) Rates of accumulation of marine debris in Chatam County, Georgia. Mar Pollut Bull 24(9):436-441

Goldberg E (1994) Editorial. Mar Pollut Bull 28(8):466

Gottfried JM, Vauk JM, Schrey E (1987) Litter pollution from ships in the German Bight. Mar Pollut Bull 18,6(B): 316-319

Laist DW (1987) Overview of the biological effects of lost and discarded plastic debris in the marine environment. Mar Pollut Bull 18,6(B):319-326

Lecke-Mitchell KM, Mullın K (1992) Distributıon and abundance of large floating plastic in the north-central Gulf of Mexico. Mar Pollut Bull 24(12):598-601

Loubersac L, Bodennec G (1982) Pollution par macrodéchets du littoral français: méthodologie et état de référence. CNEXO. France

Millot C (1987) Circulation in the Western Mediterranean Sea. Oceanol Acta 3:399-402

Millot C. Taupier-Letage I, Leborgne P, Lopez-Garcia MJ Wald L (1994) Dynamical oceanography studies from 
infrared remote sensing in the western Mediterranean Sea. Mem Inst Oceanogr Monaco 18:1-11

Millot C, Wald L (1980) The effect of mistral wind on the Ligurian current near Provence. Oceanol Acta 3(4) $399-402$

Nash AD (1992) Impact of marine debris on subsistence fishermen. Mar Pollut Bull 24(3):150-156

Nolting RF (1991) Dissolved and particulate trace metals in sediments of the Gulf of Lion. Third workshop on the north-west Mediterranean Sea, Texel, October 1991. Water Pollut Res 28:314-340

This article was submitted to the editor
Palmisano AC, Petigrew CA (1992) Blodegradabllity of plastics. BioScl 42(9):680-685

Pruter AI (1987) Sources, quantities and distribution of persistent plastics in the marine environment. Mar Pollut Bull $18,6(B): 305-310$

Takehama S (1990) Estimation of damages to fishing vessels caused by marine debris, based on insurance statistics. In: Shomura RS, Godfrey ML (eds) Proceedings of the Second International Conference on Marine Debris. Honolulu, Hawai, April 2-7, 1989. US Dept of Commerce, NOAATM-NMFS-SWFSC-154, Washington, DC, p 792-809

Manuscript first received: May 29, 1996

Revised version accepted: July 29, 1996 